\title{
HEAVY MINERALS OF THE INNER CONTINENTAL SHELF OFFSHORE THE AÇU RIVER'S DELTA (NORTHEASTERN BRAZIL)
}

\author{
HELENICE VITAL ${ }^{1}$ AND INGRED M. GUIMARÃES GUEDES ${ }^{2}$
}

\begin{abstract}
Provenance and sediment dispersal has been investigated in the northeastern Brazil. Most precisely on the inner continental shelf offshore the Açu river's delta (Rio Grande do Norte State). The heavy mineral assemblages delineated along the inner shelf faithfully reflect the various petrographic units of the source area. The distribution patterns of the principal heavy minerals indicate the major point sources of sediment supply onto the shelf and reveal intensive mixing, sorting processes and that an westerly (from east to west) longshore current plays an important role in the sediment dispersal. As a result, the mineral distribution east of the Açu River is rich in stable heavy minerals (mainly zircon and tourmaline) whilst west of the Acu River is rich in unstable ones (mainly hornblende and epidote). A mixing zone occur in front of the river where stable and unstable minerals are present. In addition to provenance-induced variability, mineralogical differences between E and W provinces could indicate that environmental processes have contributed to the total variability of the inner continental shelf sediments.
\end{abstract}

Keywords: Heavy minerals, provenance, sediment dispersal, Brazil, northeastern continental shelf

INTRODUCTION The heavy mineral study is one of the oldest fields in sedimentary petrology. It is particularly useful in studies of sediment sources and sediment transport path. Previous studies of heavy minerals in northeastern Brazil are restrict to the middle and outer shelf (e.g. Summerhayes et al. 1975, Palma 1979) or to the continent along the coast (Gillson 1950, Coutinho and Coimbra 1974). The scale of these works were, however, too large to depict regional details.

To a large extent the nature of shelf sediments reflects the geology, morphology, and erosional history of the source areas, as well as the sediment transport. So, the purpose of this paper is to present and evaluate the results of heavy mineral analysis of the inner shelf adjacent to the Açu River mouth, north littoral of the Rio Grande do Norte State. Our aims are the recognition and mapping of the spatial distribution of heavy mineral associations to furnish information on dispersal patterns and provenance.

REGIONAL SETTING The study area is located in the inner continental shelf offshore the Açu river's delta, northern littoral of Rio Grande do Norte State - NE Brazil (Fig. 1). This continental shelf averages $30-40 \mathrm{~km}$ width; and its edge is about $50-60 \mathrm{~m}$ deep. It shows an irregular morphology, with gradient around 1:1000. The shelf configuration was strongly affected by a Meso-Cenozoic vertical tectonism. Geologically, the area is part of the Potiguar Basin. The terrestrial portion of the basin has a trough limited by NE-SW faults. The offshore portion of the basin is limited by E-W and NW-SE faults that form the boundaries of a homocline dipping towards the ocean The graben and horst structures present on the Potiguar Basin played an important role on the shelf morphology and sedimentation (Guamare graben and Macau horst) (Fig. 1).

Costa Neto (1997) identifies 13 sedimentary facies to this shelf, based on sedimentary grain size and carbonate content of the samples. These facies are represented by bioclastic gravel, coarse-fine sands; bioclastic, and lithoclastic mud. A carbonate cemented sandstone facies has been identified and correlated to submerged beach rocks. The biogenic content is mainly represented by melobesya corallina algae and benthonic foraminifera, whereas in the terrigenous sediments, quartz prevails, with the secondary appearance of the heavy minerals, sandstone fragments, and iron oxide debris.

The oceanic circulation is dominated by the North Brazilian Coastal Current. Constant trade winds generate effective waves and longshore drift currents which transport the sediments from east to west, constructing longshore bars. The tidal currents promote the seaward redistribution of sediments forming an ebb tide delta; as well as landward forming a flood tide delta at the Açu River mouth (Costa Neto, 1997). The continental shelf sedimentation was influenced by eustatic changes of the sea level, resulting in the exposure of the shelf and the incision of the Açu river paleochannel, and the formation of linear and isolated reefs.

The Açu River is the most important fluvial contribution. It drains several rock types and diverse geomorphic features in its drainage basin. Because of this, the Açu River has been used to provenance and sediment dispersal patterns studies (Silva 1999, Silva and Vital, this volume). These authors identify six heavy mineral assemblages along the Açu River, and have associated each heavy mineral to the most probable source rocks.

Sousa (1998) and Sousa et al. (this volume) show that siliciclastic units of the Potiguar Basin can be typified by their heavy mineral associations, with the heavy mineral suites becoming increasingly complex from the oldest (Açu Formation) to the younger one. According to these authors, the rocks from the Açu Formation have almost no translucent minerals, rocks from Barreiras Formation are clearly enriched in zircon. The Gravel deposits are rich in epidote, and recent alluvial deposits show an increase in the unstable heavy minerals, chiefly hornblende, reflecting a continuous sediment transport from the basement.

The Figure 2 shows the averages for the most important heavy minerals observed in alluvial sediments from the Piranhas-Açu River (concerning the mineralogy of the crossed units for this river, as well as the rocks from the Açu Formation, Barreiras Formation, and Gravel deposits (Sousa 1998, Silva 1999) (Fig. 2).

METHODS The sediment samples were collected by dredge in shallow waters ranging from 2 to $25 \mathrm{~m}$ depth; and submitted to grainsize measurements by sieving at phi interval (see Costa Neto 1997, for details). The heavy minerals were separated into 50 samples using a

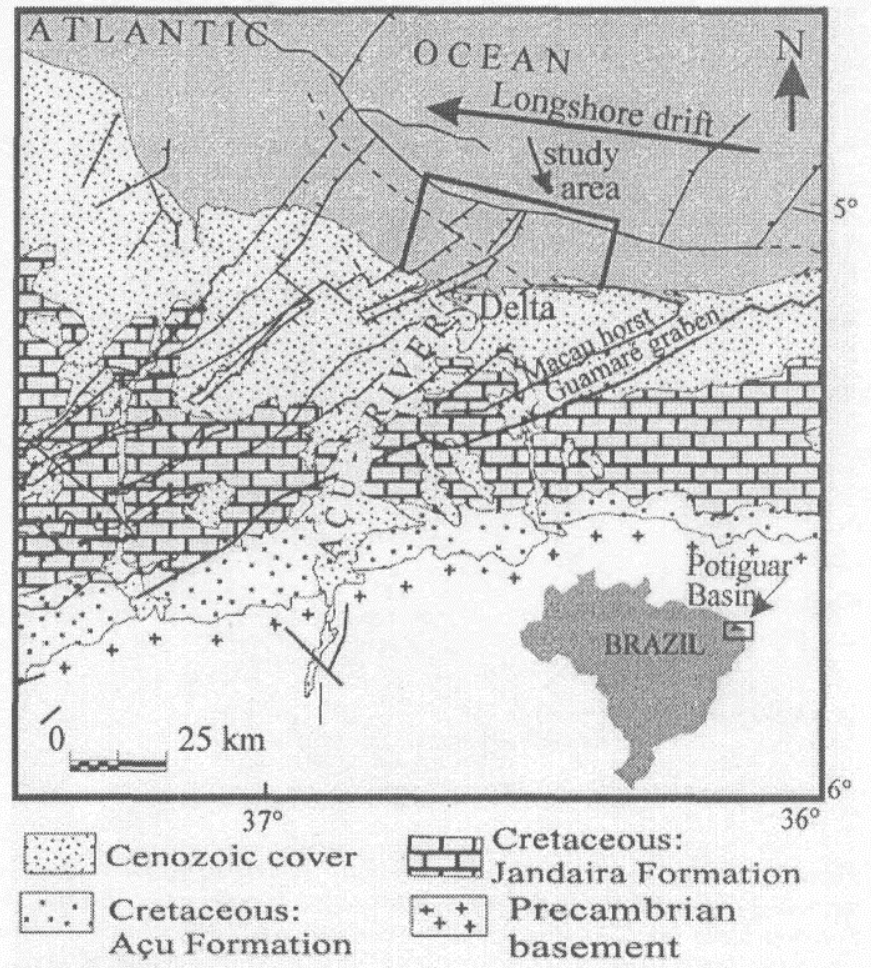

Figure 1 - Location of the Potiguar Basin and of the study area. 
sodium polytungstate solution (density $2.96 \mathrm{~g} / \mathrm{cm}^{3}$ ) as heavy liquid. The heavy mineral concentrate was washed with distilled water to remove sodium polytungstate coatings from the grains, and grain mounts (Canada Balsam as adherent media) were examined petrographically. Heavy mineral proportions were estimated in fraction $0.063-0.125 \mathrm{~mm}$ by counting at least 300 translucent detrital grains in each mounting. After careful examination and operational tests in different fraction ranges, the $0,063-0,125$ fraction was chosen on the basis of the abundance and diversity of heavy minerals. The $0.063-0.125 \mathrm{~mm}$ fraction was therefore believed to contain the most representative assemblage of heavy minerals and the maximum information; moreover, the range is sufficiently narrow to minimize both, the hydraulic effect and the variations in optical properties (Morton 1985, Morton and Hallsworth 1994).

RESULTS AND DISCUSSION A variety of translucent and opaque heavy minerals occur in the inner shelf adjacent to the Açu River. Hornblende, epidote, zircon, staurolite, kyanite, andalusite, and tourmaline are the principal constituents (those performing more than $5 \%$ ); while titanite, anthophyllite, zoisite, rutile, garnet, and sillimanite are the accessory ones (little than 5\%). Ilmenite is the main opaque mineral. The contents of heavy mineral ranges from less than $1 \%$ to 16 $\%$ in the studied fraction.

The spatial distribution of the heavy mineral constituents provides the delineation of three mineral provinces (Fig. 3). Each of these provinces is characterized by the dominance of two to three principal minerals and usually some diagnostic accessories: 1) East - Eastward of the Açu River mouth the opaque minerals are the most abundant and the translucent minerals assemblage is constituted by a predominance of very stable to stable minerals, with dominant zircon, tourmaline staurolite, andalusite, and kyanite;.2) West - Westward of the Açu River the translucent minerals are more abundant than the opaques and constitute an assemblage of unstable to stable minerals, with dominant hornblende, epidote, staurolite and andalusite. 3) Açu mouth - In front the Açu River mouth occurs a mixing zone with similar contents of opaque and translucent minerals. The heavy mineral assemblage is a mixing between unstable and very stable minerals.

The spatial distribution of the two principals translucent minerals from Province West (Hornblende and epidote) and from Province East (zircon and tourmaline) are displayed in Figure 4.

The onshore-offshore components of sediment transport, governing coastal sedimentation is well defined, and the effects of these components are reflected in the dispersal of the principal minerals. The very high proportions of hornblende to the west is attributed to the

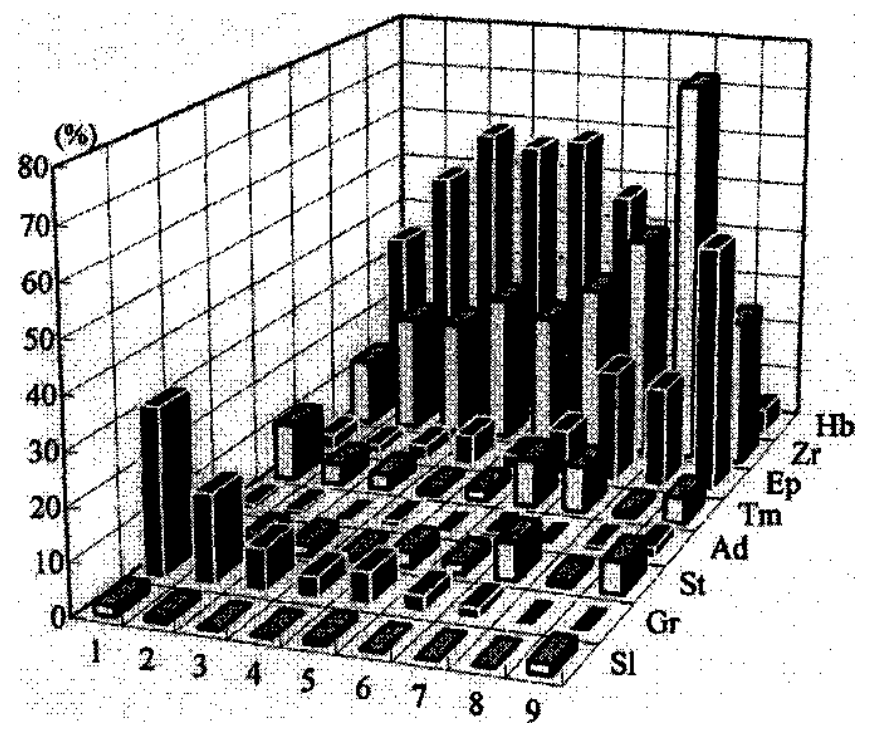

Figure 2 - Average distribution for the most important heavy minerals according to the rocks of basement units (1 to 4), and rocks and sediments of Potiguar Basin units (5 to 9) crossed by the Piranhas-Açu River. $1=$ Seridó Formation $(n=5), 2=$ Caicó Complex $(n=5), 3=$ Jucurutu Formation $(n=5)$, $4=$ Jucurutu Formation + granites $(n=J 5), 5=$ Mesozoic rocks $(n=10), 6=$ Cenozoic rocks $(n=8), 7=$ Açu Formation $(n=8)$, Barreiras Formation $(n=2)$, Gravel deposits $(n=J 2), n=$ number of samples. $\mathrm{Hb}=$ hornblende, $\mathrm{Zr}=$ zircon, $\mathrm{Ep}=$ epidote, $\mathrm{Tm}=$ tourmaline, $\mathrm{Ad}=$ andalusite, $\mathrm{St}=$ staurolite, $\mathrm{Gr}$ = garnet, $S I=$ sillimanite. provenance. The continuous transport from basement, accounts for the abundance of this mineral. The highest hornblende isopleth $(80 \%)$ close to the coast clearly shows how platy material was entrained into the shelf dispersal system (Fig. 4a). To the east, the amounts of hornblende diminish abruptly, not reaching values higher than $20 \%$.

Although the epidote distribution increases westward, close to the coast it shows similar amounts to east and to west (isopleth of 20\%).

Zircon and tourmaline, however, have a distinctly different abundance distribution which show a marked decrease eastward the Açu River (Fig. 4c, d). The highest amount of zircon is concentrated in the vicinity of the Ponta do Tubarão spit (isopleth of 30\%), in areas where the Barreiras Formation crops out in the shelf and coastal processes act more intensively. A higher percentage of opaque minerals and ZTR index (zircon + tourmaline + rutile) indicate that a higher degree of hydraulic fractionation and selective decomposition was experienced by these sediments.

These data indicate that mineralogical differences between the provinces 1 (east) and 2 (west) are related to provenance factor, as well as to more extensive hydraulic fractionation and selective decomposition of the sediments eastward the Açu river, when compared to the relatively fresh suite westward.

CONCLUSIONS The load of the Açu river is characterized by a large amount of hornblende that reached the shelf as indicated by the abundant hornblende in the sediments in front of and westerly of the Açu River. There is an abrupt change of mineral composition just west of the Açu River mouth. The alternating dominance of stable minerals to the east and unstable to the west is the main feature. Stables and very stable minerals supply may be related to both the Açu river, or to the Barreiras Formation cropping out in the littoral and in the shelf area. These conclusions are supported by the heavy mineral distribution in the shelf area which is related to longshore drift currents from east to west, as well as to the absence of another source potentially important.

In addition to provenance-induced variability, the mineralogical differences between $\mathrm{E}$ and $\mathrm{W}$ provinces could indicate that environmental processes have contributed to the total variability of the inner continental shelf sediments. The processes of selective chemical decomposition and hydraulic fractionation associated with reworking have resulted in the preferential concentration of heavy minerals characterized by higher density and stability

Acknowledgements To CNPq (grant 400197/97-9) and Projeto NE- Gestão de Sistemas Costeiros (CAPES/FUNPEC) for financial support, to L.X. Costa Neto for sample analyses, and to two anonymous referees of RBG for the critical review of the manuscript.

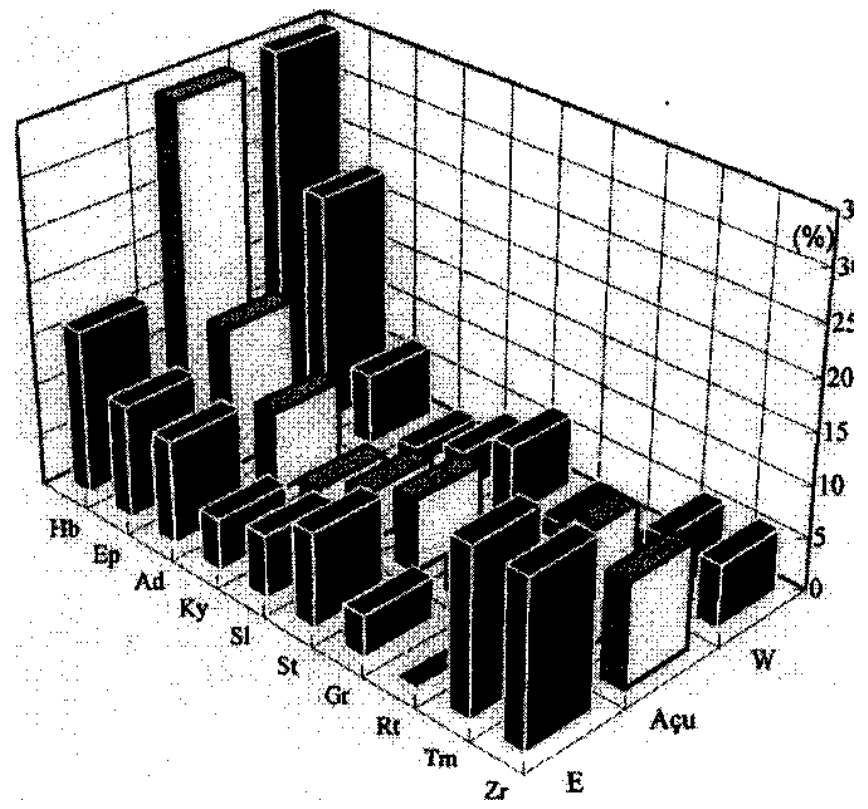

Figure 3 - Heavy mineral provinces observed in the inner continental shelf offshore Açu River's Delta. E = Eastward of the Acu River ( $n=19), W=$ Westward of the Açu River (n=9), A(u = In front the Açu River mouth (n-ll), $n=$ number of samples. $H b=$ hornblende, $Z r=$ zircon, $E p=$ epidote, $T m$. tourmaline, $A d=$ andalusite, $S t=$ staurolite, $G r=$ garnet, $S I=$ sillimanite, $K y$ $=$ kyanite, $R t=$ rutile. 

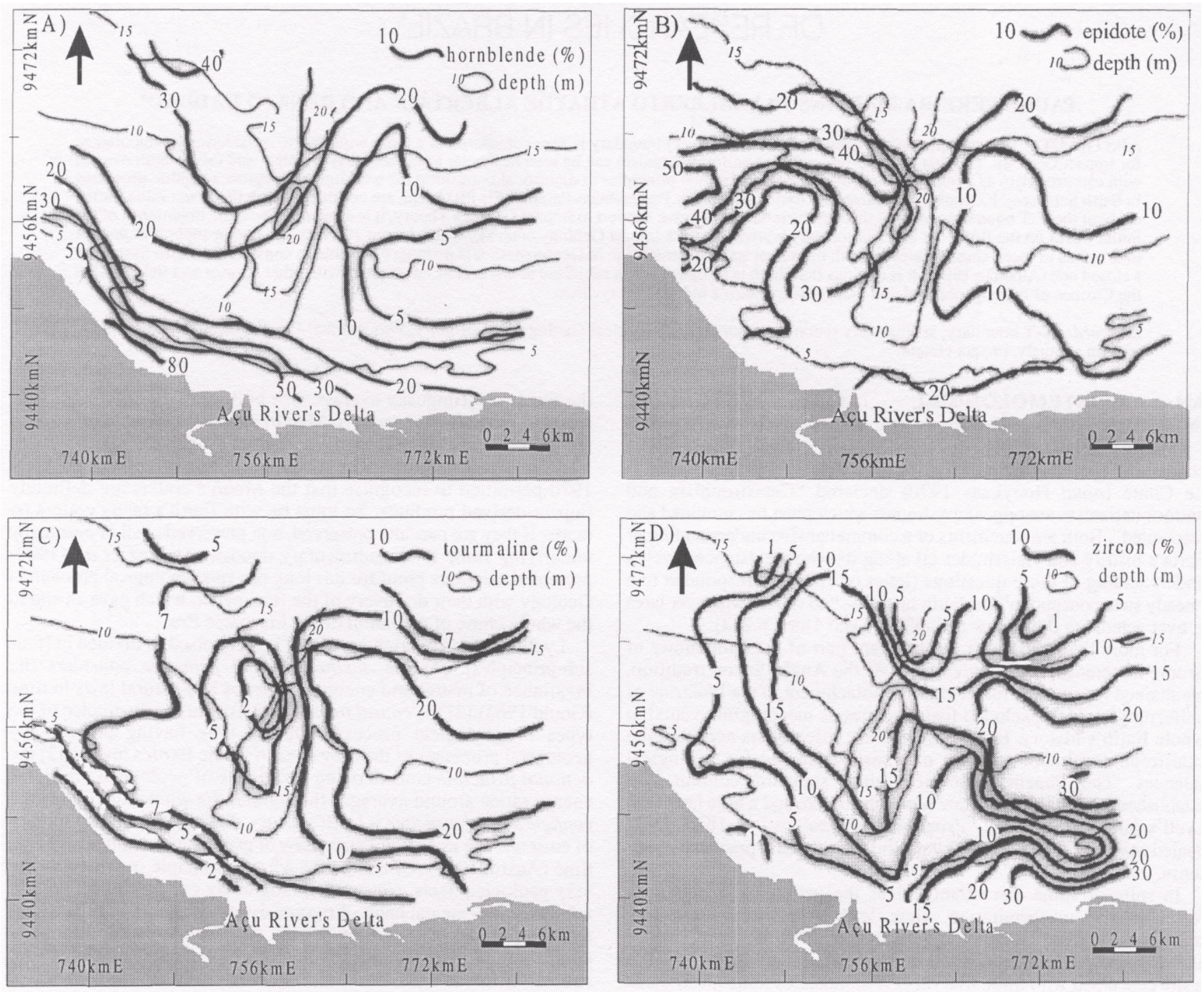

Figure 4 - Spatial distribution of hornblende (a), epidote (b), tourmaline (c), and zircon (d) in the inner continental shelf offshore the Açu River's Delta. Bathymetric data from Costa Neto (1997)

References

Costa Neto L.X. 1997. Evolução geológica-geomorfológica recente da plataforma continental interna ao largo do delta do Rio Açu, Macau-RN. Master dissertation. UFF/IG/ DGL/LAGEMAR, Niterói-RJ. $214 \mathrm{p}$

Coutinho J.M.V. and Coimbra A. M. 1974. Os pesados do Barreiras na Costa Oriental Brasileira: Estudo de Áreas -Fonte. 28 Cong. Bras. Geol. Porto Alegre, Anais. Vol5,27 41.

Gillson J.L. 1950. Deposits of heavy minerals on the Brazilian coast. Trans. A.I.M.E., 187, Mining Eng. 685-693.

Morton A.C. 1985. Heavy minerals in provenance studies. In: G.G.ZUFFA (ed), Provenance of Arenites. P 249-277.

Morton A.C. and Hallsworth C. 1994. Identifying provenance-specific features of detrital heavy mineral assemblages in sandstone. Sedimentary Geology, 90:241-256.

Palma J.C. 1979. Depósitos de minerals pesados. Recursos minerals da margem continental brasileira e das áreas oceânicas adjacentes. Série Projeto Remac, N¹0, pag. 3350.

Silva M. G. 1999. Caracterização de minerals pesados ao longo do rio Piranhas - Açu/RN Distribuição e proveniencia. Master dissertation. PPGG/CCET/UFRN. 72p. + anexos.
Silva M.G. and Vital, H. 2000. Heavy mineral distribution in Piranhas-Açu River - (NE Brazil): Implications for provenance. RBG - Brazilian contributions to 31 st International Geological Congress, Brazil, Vol.30 (1) (this volume).

Sousa D.C. 1998. Caracterização dos minerals pesados aplicada a distinção de unidades estratigráficas (Area Açu). Relatorio de Graduação. Departamento de geologia. UFRN. Natal-RN. 47p. + anexos.

Sousa D.C., Vital, H., Fonseca, V.P. 2000. Stratigraphic significance of heavy minerals in sediments of the northeastern Brazil. RBG - Brazilian contributions to 31st International Geological Congress, Brazil, Vol.30 (1)(this volume).

Summerhayes C.P., Coutinho, P.N., França, M.C., Ellis J.P. 1975. Salvador to Fortaleza Northeastern Brazil. In: Milliman, J.D. \& Summerhayes, C.P. 1975. Upper continental margin sedimentation off Brazil, Contributions to Sedimentology. Stuttgart V.4, p. 4478. 